\title{
A Step towards Distinction between Supervisory Impulsive and Strategic Abuse
}

\author{
Shahid N Khan ${ }^{1}$ \\ ${ }^{1}$ Department of Management, Monash University, Australia \\ Correspondence: Shahid N Khan, Department of Management, Monash University, Australia. E-mail: \\ shahid.khan@monash.edu
}

Received: August 25, 2014 Accepted: September 1, 2014 Online Published: October 30, 2014

doi:10.5539/ass.v10n21p281

URL: http://dx.doi.org/10.5539/ass.v10n21p281

\begin{abstract}
In this article, the researcher proposed a theoretical frame work of supervisory impulsive and strategic abuse. So for majority of the literature had focused on the supervisory impulsive abuse and its effects on employee's personal and/or professional life while the supervisory strategic abuse have enormously been ignored in the literature. The theoretical frame work offered in this paper will help to identify the boundary line between these two sub-types of abusive supervision. The researcher tried to clarify, with the help of existing literature, boundaries among the sub-types of the construct of abusive supervision e.g. supervisory impulsive and strategic abuse and integrate it into a theoretical model that helps to understand the manifestation of supervisory abusive behaviour in terms of its strategic and impulsive abuse. Further its effects on employee's morale have also been discussed in its theoretical model. Future research directions have also been discussed in this paper.
\end{abstract}

Keywords: abusive supervision, impulsive abuse, strategic abuse, employee's morale, stress, employee's job performance

\section{Introduction}

Abusive supervision has adverse effects on subordinates' performance, attitude, self-respect, turnover and physical health (Hornstein, 1996; Khan, Qureshi, \& Ahmad, 2010; Mehdi, Raju, \& Mukherji, 2012). Abusive supervision badly affects subordinates' perception of organisational justice, which ultimately affect their performance, job satisfaction, life satisfaction, organisational commitment, organisational citizenship behaviour, conflict between work and family-life and psychological distress (Kang \& Jensen, 2009; Tepper, 2000, 2007; Tepper, Duffy, Hoobler, \& Ensley, 2004; Tepper, Moss, Lockhart, \& Carr, 2007; Zellars, Tepper, \& Duffy, 2002).

It is well-known that bullying or other forms of abuse in the workplace, especially by supervisors, can affect employees' performance and productivity (Hornstein, 1996; Tepper, 2000; Tepper, Henle, Lambert, Giacalone, \& Duffy, 2008) and therefore can affect a firm's competitive advantage (Barney, 1991; Duschek, 2004; Rahimić \& Kovačević, 2009). The firm's competitive advantage is inter-related with the employee's performance and productivity (Cole, 1998). Therefore, it is argued that the employee's role is crucial in getting and sustaining a competitive advantage for the firm (Barney, 1991). If employees are suffering from abusive supervision at work, this will affect their performance and productivity, which will ultimately affect the firm's performance and productivity as they are the organisation's real asset (Cole, 1998; Tepper, 2000; Tepper, Moss, \& Duffy, 2011; Zellars et al., 2002). This ratio of abusive supervision varies from country to country and culture to culture but it is evident from the literature that this phenomenon of abusive supervision exists in almost all countries and cultures of the world.

The issue of abusive supervision at work is apparent from existing literature for organisations, employers and employees. To date, however, the majority of the work has concentrated upon its antecedents, consequences and the reasons for its occurrence that affect organisations, employers and employees (Tepper, 2007). Such behaviour motivates subordinates for deviant work behaviour the cost of which is much higher than the benefits of organisational citizenship behaviours (Dunlop \& Lee, 2004). 


\subsection{What Are the Effects of Abusive Supervision?}

Abusive supervisors get things done by force and they create intimidation and fear. Abusive supervision has implications for subordinates' performance, attitude, self-respect and physical health (Hornstein, 1996; Jian, Kwan, Qiu, Liu, \& Yim, 2011; Mariano \& María, 2008). Tepper (2000) has reported more severe effects of abusive supervision on subordinates' work and family life, including subordinates' perceptions of organisational justice, job performance, job satisfaction, life satisfaction, organisational commitment, conflict between work and family-life and psychological distress. Abusive supervision is positively related to employees' job tension, emotional exhaustion and turnover intention (Harvey, Stoner, Hochwarter, \& Kacmar, 2007; Tepper, 2000; Wu \& Changya $\mathrm{Hu}, 2009)$. It costs the organisation in terms of lost productivity, absenteeism, turnover and health care expenditures (Tepper et al., 2011).

Hornstein (1996), reported more than $90 \%$ of adult employees face emotional and psychological abuse at least once in their job life. Abusive supervision negatively affects employees. While recent research showed that around $15 \%$ of American employees are suffering from abusive supervision on a regular basis (Tepper et al., 2004), Ylldiz (2007) reported that in Turkey more than $20 \%$ of the employees are suffering from psychological abuse.

To highlight the physical effects caused by abusive supervision at work, Hockley (2002) reported a case study of an employee who felt fear and intimidation when she had to go to the office because of physical effects she had experienced in the past. These included stomach pain, diarrhoea, vomiting, headache, and insomnia. Grice, Sheehan, McCarthy, Barker, and Henderson (2003) and Hockley (2002) have reported more severe physical effects such that the victim couldn't continue his job and had to go on medical leave. In such a situation, the victim of abusive supervision could be deprived economically and physically as well as psychologically.

In the WBI (Workplace Bullying Institute) survey of 2010, 35\% of US employees (approximately 53.5 million Americans) reported being bullied at work while another $15 \%$ witnessed it. Hence $50 \%$ of all Americans have experienced bullying at work (Namie, 2010). In their 2012 survey, anxiety was reported by $80 \%$ of targets, panic attacks by $52 \%$ and agoraphobia by $17 \%$, while in the same report $49 \%$ had been diagnosed with clinical depression, sleep disorder, insomnia, loss of concentration, mood swings and pervasive sadness (Namie, 2012). According to the ILO (International Labour Organisation) violence at work, ranging from bullying and mobbing to sexual harassment to homicide, is reaching epidemic levels. In 2002, the ILO reported 800,000 victims of mobbing (bullying) in Germany and 22\% of public officials being mobbed (bullied) in Spain. Efforts to estimate the cost to employers caused by workplace bullying range from 6 to 13 billion dollars in Australia and 23.8 billion dollars in the USA (Chappell \& Di Martino, 2006; Tepper, Duffy, Henle, \& Lambert, 2006).

It should be considered that the stimuli for workplace bullying and violence may differ from person to person due to their personality differences, hierarchical levels, workplace conditions, and industry types. The term 'horizontal violence' is mainly used in North American and Australian literature (E. Duffy, 1995; Roberts, 1983). In the United Kingdom similar behaviour is recognised as bullying (Adams, 1992). The effects of workplace bullying and violence are even more severe in vertical violence than horizontal violence. Hockley (2002, p. 28) cited the case study described by Adams (1992) where one manager had strict control of employees for four years. All the men and women were working in a very depressed and miserable condition. This manager's intimidating and degrading behaviour had severely affected the employees' professional and personal confidence. The employees' complaints were not listened to by top management and the manager was even given support to disgrace employees regarding their eating habits, leading to one employee having to eat her lunch in the toilet.

\subsection{Why Does Abusive Supervision Occur?}

The occurrence of abusive supervision mainly depends upon the context in which it occurs (Hoff, 1990). Mere definitions and types of this violence and bullying are not sufficient to understand the bullying and violent behaviours. Chappell (1995), has argued that individuals who are violent in their homes have the potential to be violent in other situations. Similarly Hockley (2002) argues that it is logical to admit that the occurrence of violence somewhere else in society has the potential to bring this violence into the workplace. Social learning theory argues that behaviours usually comes through learning processes in human beings accordingly this violent behaviour comes through learning processes when people observe someone especially a role model, behaving violently (Bandura, 1973, 1986). One factor or reason for the occurrence of abusive supervision, therefore, is the social learning process through which the supervisors makes the cognition to be abusive like his/her role model and this cognition becomes a personality trait which motivates him/her to be abusive towards subordinates.

Hockley (2002, p. 18) cited Bull (1993; pp. 6-8) who reported seven reasons behind the occurrence of abusive or violent behaviour at work: (1) Disappointment or frustration with service, (2) Drug and alcohol habits, (3) 
Trouble-making clients or employees, (4) Using others for success and achievements, (5) Deceitful benefits, (6) Organisation and top management motivation and support for such behaviour to get things done, can have influence beyond the original targets and extend to (7) Third party experience of violence and abuse. In this context, abuse of power is identified as a factor or reason for abusive supervision, especially in teams (Vecchio \& Brazil, 2007).

Contrary to these reasons, Chappell (1995) has argued that violence usually occurs between persons who know each other. He stresses the element of familiarity in the occurrence of violence. While Hockley sees this phenomenon more broadly and concluded that violence is a subjective assessment and some may perceive it as violence and some may not. Hockley (2002, p. 24), explained that 'The term violence is often used interchangeably with other terms, such as abuse, bullying, harassment, and psychological terrorism. All of these terms imply some form of harm to another person (victim)'.

\subsection{Other Related Topics}

Some closely related topics have also been discussed to differentiate abusive supervision from these areas, e.g., mobbing, bullying, workplace aggression, leader member exchange theory, occupational violence, deviant work behaviour, social support, perceived organisational support, and perceived supervisory support etc.

Mobbing and abusive supervision. Leymann (1998), introduced the concept of mobbing in the workplace in early 1980s when he observed similar behaviour in the workplace as that which occurred in animals and schools. The term 'mobbing' derives from the situation when a group of smaller animals attacks a single large animal.

Mobbing is ganging upon someone using rumours, innundo, discrediting, humiliation, isolation and intimidation in a concentrated and direct manner. Mobbing is a non-sexual, non-racial form of workplace harassment that is subtle and subversive (Leymann, 1990; Zapf, Knorz, \& Kulla, 1996). The first investigation of mobbing occurred in mid 1980s (Einarsen, 1999; Leymann \& Gustavsson, 1984; Niedl, 1996). It was reported in Western Europe and the USA only after 1992 (Groeblinghoff \& Becker, 1996).

In mobbing, the person who is being attacked is portrayed as the person at fault (Hogh \& Dofradottir, 2001; Invernizzi, 2000). Tehrani (2012), reported factors that are associated with mobbing to be office politics and corporate culture, unclear expectations, dishonesty, withheld information, discouraging responses, tolerance of poor performance, being taken for granted. Behavioural changes often precede workplace violence. These changes may include increased agitation, pacing, sudden unusual calmness, shouting, hostility, tearfulness, clenched fists, invasion of body space, or expression of paranoid thoughts (Brennan, 1996). Sweden-based German medical scientist Leymann (1990) founded an international bullying movement that he named 'mobbing' and defined it as sustained violence by a group of employees on a single co-worker.

It is argued that the term 'mobbing' is more focused on horizontal violence, e.g., violence between colleagues rather than the vertical violence where supervisor abuses his/her subordinates. The former is more prominent in the USA and Australia (Duffy, 1995; Roberts, 1983) while in the United Kingdom such behaviour is termed 'bullying' (Adams, 1992). Keeping in view the above arguments about the term mobbing, it is argued that mobbing is beyond the scope of the present study because of its horizontal approach, but is related to supervisory abuse in terms of the vertical relationship between supervisors and subordinates.

Bullying and abusive supervision. Workplace bullying is recurring, undesirable, psychological, physical or sexual abuse or harassment from one employee towards other employees at work (MacIntosh, 2006). The concept of bullying has got attention, particularly, when it transferred from a schoolyard setting into the workplace in the early 1990s (Adams, 1992; Hockley, 2002).

According to Ireland's government definition, bullying is recurring rude and ridiculing behaviour, intended or unintended, verbal or non-verbal directed by one person or group of persons towards another person or group of persons, and can happened in the workplace or outside the workplace. The intention of such behaviour is to disgrace, humiliate or abuse the individual and impinge upon his/her right to dignity at work (Health \& Safety Authority, 2013). A similar definition of bullying appears in South Australia's Occupational Safety and Health Code as a behaviour that is intended to harm, humiliate and abuse psychologically or physically an employee or group of employees on a regular and systematic basis (Government of South Australia, 2013). The Canadian province of Quebec's labour standard (Sec 81.18) that became effective in Jun, 2004, refers to bullying as 'psychological harassment at work' with a further explanation that it is an annoying and irritating behaviour that reveals itself in activities, gestures and verbal comments that tease and ridicule a person on regular basis which affect the person's dignity and self-esteem in a work environment ("Labour Laws," 2002). 
French and Morgan (2002), in the Canadian Survey of Labour Unions report in 2000, stated that more than 70\% of employees reported workplace harassment and bullying. Bullying is a hurtful and repeated mistreatment of people by their bosses, co-workers and/or subordinates. The bullying definition also includes abuse of power which has adverse effects on a person's life (Turnbull, 1995). Further, Adams (1992) and Hockley (2002) have identified and highlighted some features of bullies' behaviour which include frightening and underestimating people, attacking others' personalities, changing their duty rosters without notification and discrediting them in their jobs and activities. Lines (2008), listed synonyms for bullies to include aggressors, mobbers, offenders, backstabbers, saboteurs, harassers, nit-pickers, control freaks, obsessive critics, terrorists, tyrants, perpetrators and abusers. He further added that everyone considers bullying a wrong and unacceptable attitude and behaviour, and that the one who commits bullying can be identified by everyone.

In keeping with the above-mentioned ideas, it is argued that bullying is a general term which includes all horizontal and vertical abuses, e.g., abuse from supervisors, peers, and/or subordinates. It is worthwhile mentioning that other types of bullying (e.g., bullying by subordinates and colleagues) are beyond the scope of present study while vertical bullying (e.g., a supervisor's bullying behaviour towards his/her subordinates) falls under the scope of the present study.

Workplace aggression and abusive supervision. Workplace aggression includes any form of behaviour by a current or former employee that is intended to harm co-workers or the organisation (Folger \& Baron, 1996). Workplace aggressions are physical or verbal attacks (Baron \& Neuman, 1998; Cashdan \& Downes, 2012; Crick \& Dodge, 1994; Folger \& Baron, 1996). The domain of workplace aggression includes both horizontal and vertical aggression and even aggression from the organisation's former employees. It also includes physical and non-physical attacks (Baron \& Neuman, 1998).

It is therefore argued that upward aggression, from employees to supervisors and horizontal aggression, between subordinates and peers, or from former organisational employees are beyond the scope of present study. As abusive supervision is one form of non-physical workplace aggression (Hoobler \& Brass, 2006; Mitchell \& Ambrose, 2007) it is linked with the present study in terms of its supervisory non-physical abuse. Therefore, supervisory abuse falls into the sub-domain of workplace aggression.

LMX theory and abusive supervision. Initially the Leader-Member Exchange (LMX) theory developed by Dansereau, Cashman, and Graen (1973) was originally Vertical Dyad Linkage (VDL) theory, and was based on an assumption that a leader's behaviour may vary from member to members. It will be more homogenous and consistent towards specific members rather than general members. Graen, Novak, and Sommerkamp (1982), renamed it, calling it Leader-Member-Exchange theory. Liden and Graen (1980), divided it into two categories: the in-group (characterised by high trust, interaction, support, and formal/informal rewards) and the out-group (characterised by low trust, interaction, support, and rewards). Almost all leaders at work differentiate their subordinates in this way.

Leaders choose subordinates for their in-group on the basis of their expertise, talent, skills, level of confidence and trust (especially when assigning a task to subordinates), and their level of commitment and responsibility while performing tasks assigned by their supervisor. When subordinates show discretionary behaviour (going beyond their formal job duties), demonstrating a level of commitment and responsibility during the task completion, they receive favour, support, and recognition from their supervisors (Dansereau, Graen, \& Haga, 1975; Liden \& Graen, 1980).

In contrast to in-group members, out-group members have less access to and support from the leader, less recognition and reward, decreased trust and confidence from leaders, which negatively affects the subordinate's perception of the LMX relationship (Dienesch \& Liden, 1986). Being members of an ignored group, they perceive this LMX relationship to be very poor and low. Their perceptions of low-quality LMX relations are closely linked with their supervisor's abusive behaviour. When they perceive their supervisor as abusive, they also perceive poor LMX relations with their supervisors (Martinko, Sikora, \& Harvey, 2012). On the basis of conceptual similarities between abusive supervision and poor LMX relations, Martinko et al. (2012) proposed in their recent study a positive relationship between a subordinate's perception of abusive supervision and the degree to which they perceive poor LMX relationships.

Leaders form an in-group within an organisation to accomplish their tasks and to obtain excellent performance from the in-group members because, as head of the unit, the leader is responsible for good performance of the unit. According to this theory, a leader focuses on one aspect of the project and considers only those subordinates for his/her in-group who have the potential to succeed in the project. During this whole process, the leader ignores the rest of the employees under his/her command. And out-group members being ignored and 
neglected perceive a low LMX relationship with their supervisors. Does this add to their perception of abusive supervision? These out-group members are likely to label the leader as an 'abusive supervisor'. This could be a factor of abusive supervision from an employee's perspective.

Deviant work behaviour and abusive supervision. Deviant behaviour is also termed as 'abnormal individual behaviour', and includes wrong, threatening, sick, or abnormal behaviour. Societal reactions term it a 'situational offense' or 'impropriety'. But this behaviour is distinguished from criminal behaviour which is a violation of rules, regulations, and/or legal codes. Such behaviour is punishable within society (Robinson \& Bennett, 1995). According to this theory, deviant behaviour is classified as 'mental illness' and caused by a mental disorder. This theory distinguishes the individual's deviant behaviour from his/her personality (Siporin, 1965). The construct of deviant work behaviour has been defined by Robinson and Bennett (1995, p. 556) as behaviour 'deemed deviant when an organisation's customs, policies, or internal regulations are violated by an individual or a group that may jeopardize the well-being of the organisation or its citizens'.

Taylor (2005), in her detailed study hypothesised that there exists positive relationship between abusive supervision and workplace deviance, the higher the abusive supervision, the higher the workplace deviance. One cause of an employee's deviant behaviour within an organisation is abusive supervision (Mitchell \& Ambrose, 2007). This deviant work behaviour directed towards supervisors (supervisor's directed deviance), organisation (organisational deviance) or employees other than supervisor (interpersonal deviance). Hence Mitchell and Ambrose (2007) found that abusive supervision is positively related to all types of employee deviance.

This deviant workplace behaviour can cost the organisation in terms of lost productivity, performance, employee's absenteeism, sexual harassment (Everton, Jolton, \& Mastrangelo, 2007). Abusive supervision is a source of and factor in employees' deviant work behaviour at work. This deviant behaviour is linked with the focus of the present study in the context of employees' responses to supervisors' abusive behaviour. This could lead employees to deviant work behaviour. Hence it is argued that abusive supervision is closely linked with deviant work behaviour, especially employees' deviant work behaviour, and is a motivating factor for this behaviour.

Social Support and abusive supervision. According to Hobman, Restubog, Bordia, and Tang (2009, p. 237) social support is 'behaviours that are intended to assist others'. It includes support from a variety of people, e.g., spouse, sibling, friends, peers, supervisors, and neighbours, etc. (Hobman et al., 2009; LaRocco \& Jones, 1978). However Arnault (2002) defined social support a bit differently, and linked it with cultural understandings that shape it according to the need, situations/circumstances and the people who need it.

Interpersonal relationships have a strong effects on an individual's psychological well-being (Hobman et al., 2009) and plays an especially significant role in poor relationships between supervisors and subordinates. They argued that where there is high supervisory support, there exists a positive relationship between abusive supervision and anxiety, while negative support for abusive supervision and self-esteem and psychological well-being.

Contrary to this argument, the cognitive dissonance theory (Festinger, 1957) argues that when subordinates are confronted with conflicting behaviours - support and abuse from the same source, e.g., a supervisor, this creates more anxiety and incongruence. While this argument is further supported by G. Blau (1981) he adds that the source of support and stress needs to be different otherwise it won't be effective in a supervisor - subordinate relationship. At the same time, the subordinate may think 'my supervisor abuses me' and 'my supervisor offers support to me'. Such conflicting perceptions create tension and strain (Festinger, 1957; Harmon-Jones, 1999). The concept of social support is quite distinct from abusive supervision, as it supports development of positive relationships while abusive supervision causes negative behaviours (Hobman et al., 2009; Tepper, 2000). To validate this argument, it is worthwhile to mention the study of supervisory undermining conducted by E. Duffy, Michelle, Ganster, and Pagon (2002) in which they found that social support is distinct from supervisory undermining, while the concept of supervisory undermining is closely linked with abusive supervision (Tepper, 2007). Hence, it is argued that abusive supervision is a totally a different construct from social support.

Therefore, it is argued that social support and abusive supervision are related and linked with each other on at least one point - when an abusive supervisor tries to socially isolate the subordinate to give them mental and psychological torcher. In such severe situations, the subordinate might be in need of some social support, e.g., organisational support, peer support, supervisory support, spouse support etc (Hobman et al., 2009; LaRocco, House, \& French Jr, 1980; LaRocco \& Jones, 1978) to cope with abusive supervision at work. Hence Festinger (1957) cognitive dissonance theory supports and identifies the factor and reason for supervisory behaviour to be abusive towards subordinates. 
Perceived supervisory support and abusive supervision. Perceived supervisory support (PSS) is defined by Dysvik and Kuvaas (2012, p. 652) thus: 'PSS is an employee's shared views concerning the degree to which their immediate line manager values their contribution and cares about their well-being'.

According to social exchange theory P. M. Blau (1964) and, Dysvik and Kuvaas (2012) argued that in response to a high level of supervisory support, employees reciprocate by helping and supporting their supervisors to succeed in their business-unit goals. Because first-line managers and supervisors are the representatives of the organisation, employees trust them rather than their peers or the organisation (Dysvik \& Kuvaas, 2012). Furthermore, employees are aware that the line manager's evaluation would convey a good or bad message to top management about their performance and contribution and that the line mangers can provide opportunity to them for training and development (Renwick \& MacNeil, 2002). Such favour and support from line managers significantly influences employees' performance-related attitudes and behaviours at work (Bowen \& Ostroff, 2004; Truss, 2001).

But as earlier mentioned, support and abuse from the same source creates even more anxiety and incongruence in subordinates (Festinger, 1957). Hence these lines of reasoning produce a link between abusive supervision and supervisory support. Subordinates could consider supervisory support as a factor of and reason for the occurrence of abusive supervision at work.

Perceived organisational support and abusive supervision. Perceived organisational support is based upon an assertion that 'employees might develop a general belief concerning the extent to which the organisation values their contributions and cares about their well-being' (Hutchison, Sowa, Eisenberger, \& Huntington, 1986, p. 501). Perceived organisational support is now referred to and famous as POS (Eisenberger \& Stinglhamber, 2011). This phenomenon of organisational support varies within an organisation and from one organisation to another. Those organisations that consider their employees as valued human capital and a source of competitive advantage (Barney, 1991) produce high perceived organisation support while the others produce low perceived organisation support. Eisenberger and Stinglhamber (2011, p. 30), cited in their book a story about a retired head of a university graduate programme who highlighted the positive aspects of POS.

'Thirty years ago, I was walking to my mail box at school and I noticed a letter from the university president's office. I opened it up and it was a personal letter to me from the president saying he knew of my contributions and thanking me for them. And the letter contained a check for a thousand dollars. Can you imagine? He took the time to find out about my work and he showed how much he appreciated it'.

This type of appreciation from organisation's representatives gives a clear indication to employees that the organisation takes care of them and such appreciation produces high POS for the organisation, whereas the abusive behaviour from the organisation's representatives, regardless of whether it is their own personal behaviour or the organisation is supporting them in such behaviours, would produce low POS for the organisation (Shoss, Eisenberger, Restubog, \& Zagenczyk, 2013) which ultimately affects the employee's discretionary behaviour and OCB (Organisational Citizenship Behaviour). Tepper et al. (2004), heightens counterproductive work behaviour directed against the organisation and lowers in-roll and extra-roll performance (Shoss et al., 2013). This bad or abusive behaviour from organisational representatives earns a bad reputation for the organisation in employees' views and perceptions.

\subsection{Summary of Literature Review}

From the above literature review it is argued that abusive supervision is a subjective assessment and varies from person to person but has negative effects on an employee's performance, job satisfaction, and psychological health. It costs the organisation in term of lost productivity, absenteeism and turnover (Tepper et al., 2011). The present literature identified factors and reasons of its occurrence at work such as abusive supervision coming through social learning processes (Bandura, 1973, 1986), personality factors (James P. Burton \& Hoobler, 2011), cultural factors (Kang \& Jensen, 2009; Lian, Ferris, \& Brown, 2012), organisational factors, e.g., abuse of power (Vecchio \& Brazil, 2007), stressful working environments (Hauge, Skogstad, \& Einarsen, 2010), employees' perceived lower performance (Olweus, 1978; Tepper et al., 2011), leader-member-exchange theory (Liden \& Graen, 1980; Martinko et al., 2012), and an authoritarian leadership style (Aryee, Li-Yun, Zhen Xiong, \& Debrah, 2007).

The majority of the studies have also concentrated upon its consequences: work-family conflict (Hoobler \& Brass, 2006; Tepper, 2007), lower job performance (Harris, Kacmar, \& Zivnuska, 2007), lower job and life satisfaction (Tepper, 2000; Tepper et al., 2004), decreased self-esteem (James P Burton \& Hoobler, 2006), psychological distress (Tepper, 2000, 2007) and increased deviant behaviour (Mitchell \& Ambrose, 2007; Thau, Bennett, Mitchell, \& Marrs, 2009), negative employee's outcomes such as job tension, emotional exhaustion and 
turnover intention (Harvey et al., 2007; Khan et al., 2010), supervisors' perceptions of organisational justice (Hoobler \& Brass, 2006; Taylor, 2005; Tepper et al., 2006; Zellars et al., 2002), mental exhaustion and job burnout (Tepper, 2000), and abusive supervision's effects on organisational citizenship behaviours (Rafferty \& Restubog, 2011; Tepper et al., 2004; Zellars et al., 2002), negatively affects organisations in terms of absenteeism, lost productivity and turnover (Tepper, 2007; Tepper et al., 2011).

The terms such as abuse, mobbing, bullying, workplace aggression, and occupational violence/workplace violence are all used inter-changeably (Hockley, 2002; Lines, 2008). But all these terms are broad and general in nature in that abuse/bullying/mobbing/aggression can occur in an organisation horizontally and/or vertically. This kind of behaviour can be exhibited by peers, employers, supervisors, subordinates, customers and former employees. But the focus of the present study is on the vertical relationship, especially the relationship between supervisor and his/her subordinates, i.e., abusive supervisory behaviour towards employees. Other related theories, such as leader member exchange theory, have identified the reason for its occurrence in an organisation when it resulted in deviant work behaviour. Although social, organisational, and supervisory support can help to decrease the adverse effects of abusive supervision, it is evident from the above literature that where employees perceive organisational support to be low, they do not support each other against a supervisor's abusive behaviour, so this could be one reason for abusive supervision within an organisation.

From the above literature review, it is evident that this field is dominated by studies that have focused on the factors/antecedents and consequences of abusive supervision while there is a need to identify the aspects and features of abusive supervision from the employee's perspective especially those employees who have faced this phenomenon. In this regard, the researcher in the present study with the help of literature review identified, two types of supervisory abuses e.g., supervisory impulsive and strategic abuse which will further help the employees, employers and organizations to differentiate between these two types of abuses.

\section{Effects of Abusive Supervision on Employees' Job Performance}

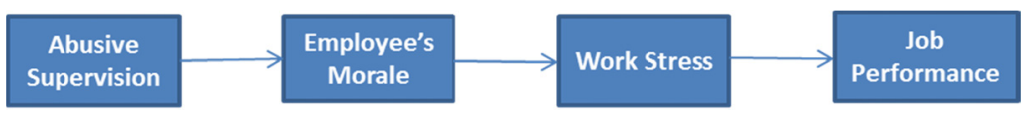

Figure 1. Effects of abusive supervision on employees' job performance

Effects of abusive supervision on employee's morale. Morale is the enthusiasm and spirit that motivates employees toward their work situation and challenges (Agarwal, 1983). Pestonjee and Singh (1977, p. 86) defined it as 'a general attitude of workers based upon their faith in fairness of employer's policies and behaviour, adequacy of immediate leadership, a sense of participation in the organisation and an overall belief that the organisation is worth working for'. In this regard, Kathirvel (2010) argued that employees' morale is not static but fluctuates up and down. The employees in the organisation are distinguished from each other on a high- or low-morale basis. The predictors of high morale are, loyalty, resistance to frustration, enthusiasm, spirit, etc., and predictors of low morale are, laziness, lack of interest in one's job, pessimism, and disobedience of the leaders.

A study conducted by Hill (1954) identified three factors of employees' morale. These are, a sense of security, a feeling of personal status, and job satisfaction. A more detailed and comprehensive study conducted by Baehr and Renck (1958) identified five factors that affect employees' morale. These factors are, organisation and management, immediate supervision, material rewards, fellow employees and job satisfaction. The present study focuses on the effects of abusive supervision on employees' morale in the context of its factor related to 'immediate supervision', which is the second highest factor affecting employees' morale after 'material rewards' in the five factor model of employees' morale (Baehr \& Renck, 1958). In a work environment, supervisors mostly interact with employees on top management's behalf, and vice versa (Pestonjee \& Singh, 1977). Due to their high level of interaction with employees, usually to the worker his supervisor is his company (Harrell, 1958).

The most important factor influencing employees' morale is their immediate supervisor's behaviour (Baird \& Bradley, 1978) and supervision style (Pestonjee \& Singh, 1977). Non-authoritarian or laissez-faire leaders have positive effects on employees' morale as compared to authoritarian leaders (Baird \& Bradley, 1978; Shaw, 1954). A participative management style has strong positive effects on employees' job satisfaction, provided that this participation is reflected in real decision making (Falcione, 1974). As earlier mentioned, immediate supervisors interact with subordinates on behalf of top management and the organisation, and vice versa. Therefore, 
supervisors' communication styles (Baird \& Bradley, 1978) and the way they clarify an employee's job objectives and roles can result in high employees' morale (Ivancevich \& Donnelly Jr, 1974; Maher \& Piersol, 1970; Rizzo, House, \& Lirtzman, 1970; Tosi, 1971).

Contrary to positive supervision, abusive supervision is negatively correlated with employees' morale (Chang \& Lyons, 2012). Employees' morale is linked with supervisory aggression through their LMX relationship; low quality of this relationship results in decreased employees' morale (Chang \& Lyons, 2012). Chang and Lyons further argued that aggression perpetrated by co-workers has direct negative effects on employee's turnover intention, while supervisory aggression results in an employee's turnover intention through a pathway of decreased employee morale. Employee job satisfaction is a factor in and source of employee morale, as the majority of the studies conducted in the domain of abusive supervision have found job satisfaction is an employee's attitude towards his job (Brief, 1998), and is negatively correlated with abusive supervision (Breaux, Perrewé, Hall, Frink, \& Hochwarter, 2008). Emotions created by abusive supervision at work, have severe effects on job satisfaction (Richman, Flaherty, Rospenda, \& Christensen, 1992) and feelings and frustrations significantly affect job satisfaction particularly when one has low job mobility (Tepper, 2000). Hence, the researcher, based on the existing literature review developed the proposition that...

Proposition 1. Abusive supervision is negatively correlated with employee's Morale such that higher the abusive supervision and lower the employee's Morale.

Effects of employees' morale on work stress. Stress can be caused due to external environmental effects over individuals, and by their responses to these affects. These environmental effects are referred to as 'psychosocial stressors' and affect individuals through a psychological stress process (Ganster \& Perrewé, 2011). In this process, environmental events are referred to as 'stressors' and the individual responses are referred to as 'strain' (Griffin \& Clarke, 2011). This concept is initially derived from the engineering concept of stresses and strain (Lazarus, 1993, p. 2), and works as a stimulus. Lazarus defined stress as 'an external load of demand on a biological, social or psychological system'. Further, Sanders (1983) argued that stress is the state of imbalance of energetical supply which is hard to restore. Stress as a response strategy is rooted in the biological work of Selye (1976). He argued that stress is the psychological response to stressors involving all body organs which in the long term weakens the body's defence system and is reflected in the subject's emotional responses, e.g., anxiety, anger, irritation, depression and inability to concentrate (Hart \& Cotton, 2003; Hart \& Wearing, 1995; Hart, Wearing, \& Headey, 1995; Selye, 1976). Selye differentiated between distress (negative stress) which is associated with negative feelings and eustress (positive stress) associated with positive feelings that motivate individuals towards their higher achievements (Coon \& Mitterer, 2008; Selye, 1976). Further Selye defined it as 'the non-specific response of the body to any demand' (Selye, 1976, p. 63). Similarly Ganster and Rosen (2013, p. 1088) defined stress as 'the process by which workplace psychological experiences and demands (stressors) produce both short-term (strains) and long-term changes in mental and physical health'.

Therefore, it is argued that stress is an internal situation or feeling caused by response to an external situation. If the situation is good and positive, it causes eustress or positive stress. If not, it causes distress or negative stress. According to dynamic equilibrium theory by Hart and colleagues (Hart \& Cotton, 2003; Hart \& Wearing, 1995) morale and psychological distress are qualitatively different but are part of a bipolar continuum. This argument is also supported by Bradburn (1969) in his theory of emotions, who finds that morale and stress are independent constructs but add equally to the quality of life. This can be observed as changes in individual's morale; low-morale is associated with individual distress, while high-morale individuals can effectively cope with the stress situation at work (Ford, 2004). Hence, the researcher, based on the existing literature review developed the appended below proposition.

Proposition 2. Employee's Morale is negatively correlated with employee's job stress such that higher the employee's morale and lower the employee's job stress.

Effects of work stress on employees' job performance. Job performance is based on the organisation's expectations for accomplishing the assigned task over a standard period of time (Motowidlo, 2003). It is the individual's ability to perform the given task within the due timeframe (Jamal, 1984).

In a meta-analysis study conducted by Muse, Harris, and Feild (2003), in which 52 studies were reviewed, 24 (46\%) supported the negative linear theory, 7 (13\%) supported the positive linear theory, 2 (4\%) supported the inverted-U theory, $13(25 \%)$ had mixed results, and $6(12 \%)$ found no relation between stress and performance. According to this meta-analysis, the majority of the studies reported that there exists a negative relationship between work stress and an employee's job performance. The majority of the work to date has empirically supported this argument that there exists a negative relationship between stress and employee's job performance; 
the higher the stress level, the lower the employee's job performance (Arshadi \& Damiri, 2013; Jackson \& Schuler, 1985).

Contrary to this argument, Jamal (2011) argued that employees with low job stress are less motivated to improve their job performance. Based upon his model, it is argued that a moderate amount of stress can play a crucial role in energising and motivating employees towards better job performance. Hence, a moderate or high level of stress is the source of employees' high performance. Jamal supported his model with Meglino (1977). He viewed stress as a challenge in the context of job performance, and used the following terms inter-changeably: problems, anxieties, difficulties and challenges. Support for this model is based upon research in a laboratory setting (Cohen, 1980) while real work situational support is missing. Similar types of stress, e.g., hindrance or negative stress and challenge or positive stress have been studied by LePine, Podsakoff, and LePine (2005) who found that the former have negative effects on performance while the latter have positive effects on performance.

This line of reasoning (Arshadi \& Damiri, 2013; Friend, 1982; Gupta \& Beehr, 1979; Jamal, 1984, 2011; Westman \& Eden, 1991) finds that what is referred to as stress is a negative external environmental having an effects on individuals, which as a result badly affects employees' job performance and is negatively correlated with employees' job performance. Hence, the researcher, based on the existing literature review developed the appended below proposition.

Proposition 3. Employee's job stress is negatively correlated with employee's job performance, Higher the job stress; lower the employee's job performance.

\section{Types of Abusive Supervision}

In the above-mentioned literature review, the researcher discussed abusive supervision, its antecedents and consequences and especially the factors and reasons for its occurrence through some related topics, e.g., mobbing, bullying, workplace aggression, leader-member exchange, leader-member-exchange theory, occupational violence, deviant work behaviour, social support, perceived supervisory support, and perceived organisational support. In a recent study, Tepper, Duffy, K., and Breaux-Siognet (2012), have narrowed down the phenomenon of abusive supervision and determined the reasons for its occurrence to be two types of abusive supervision; impulsive and strategic. They argued that impulsive abuse is exhibited by supervisors in a natural way towards subordinates without any calculation and preplanning. However, strategic abuse is coldly calculated abuse, exhibited by supervisors in the best interests of the organisation and subordinates, through enhancing subordinates' performance. This study is the extension of the study by Tepper et al. (2012) 'Abusive supervision as political activity: distinguishing impulsive and strategic expressions of downward hostility' in which Tepper and colleagues have focused on the supervisor's abusive behaviour and especially the awareness and understanding of the phenomenon of 'abusive supervision' in terms of its 'impulsive and strategic expressions of downward hostility' (Tepper et al., 2012, p. 194). This type of study has been conducted by Ferris, Zinko, Brouer, Buckley, and Harvey (2007) in which they referred to impulsive and strategic abuse as assertive tactical and assertive strategic abuse.

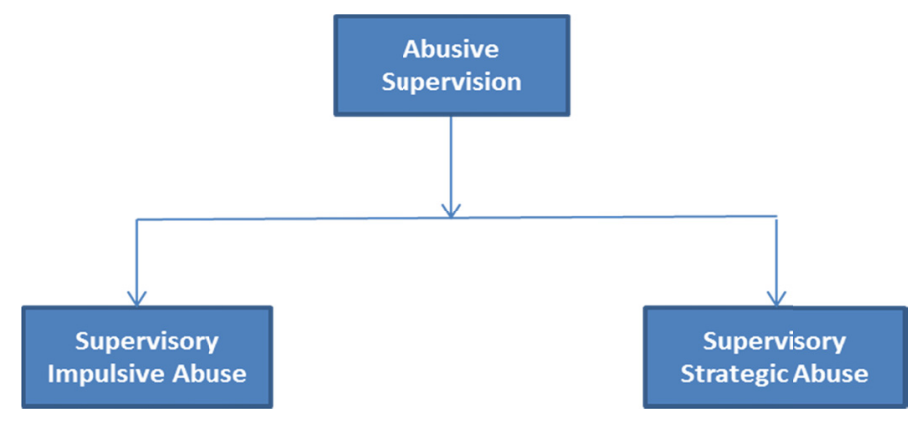

Figure 2. Types of abusive supervision

Supervisory impulsive abuse. Impulsive abuse is defined by Tepper et al. (2012, p. 194) as 'automatic and uncontrolled actions that may occur outside the supervisor's awareness'. Somewhat contrary to this definition, Ferris, Zinko, et al. (2007) referred to it as 'assertive tactical abuse' and argued that these behaviours are exhibited by a person in order to establish identity, not as a reaction to situational factors but with clear short-term goals towards employees. Intimidation has been characterised as an influence tactic in the domain of assertive tactical abuse (Sadler, Hunger, \& Miller, 2010). Intimidation is one of the five impression-management tactics identified by Jones and Pittman (1982, p. 236) that create fear and threat. Jones and Pittman (1982, p. 
236), defined it as a tactic 'whereby individuals seek to be viewed as intimidating by threatening or bullying others'. Such behaviours include aggressiveness, intimidation, bullying, and threatening (Bolino \& Turnley, 1999). Bullying/abuse and intimidation both have the same dictionary definition as someone who threats or tyranny over others (Ferris et al., 2007).

The majority of the studies conducted in the domain of abusive supervision have characterised abusive supervision as a hot or impulsive negative behaviour (Adams, 1992) because of a lack of understanding regarding its strategic or cold aspect. Therefore, it is argued that all these terms, e.g., abuse, bullying, aggression and intimidation are synonymous with each other. Hence, supervisory abusive or bullying behaviour has adverse effects on subordinates' performance, attitude, self-respect, turnover and physical health (Hornstein, 1996; Mehdi et al., 2012) and it is negatively correlated with employees' morale (Chang \& Lyons, 2012). Hence, the researcher, based on the existing literature review developed the appended below proposition.

Proposition 4 (a). Supervisory impulsive abuse is negatively correlated with employee's morale such that higher the supervisory impulsive abuse, lower the employee's morale.

Supervisory strategic abuse. Strategic abuse is defined as 'thoughtful and deliberate expressions of hostility that are performed with specific objectives in mind' (Tepper et al., 2012, p. 194). Strategic abuse is a strategy used by supervisors to achieve their personal and/or organisational goals (Ferris, Zinko, et al., 2007) which could be used as an effective management tool in an organisation. They further defined it thus: 'leader bullying represents strategically selected topics of influence by leaders designed to convey a particular image and place targets in a submissive, powerless position whereby they are more easily influenced and controlled in order to achieve, personal and/or organisational objectives' (Ferris et al., 2007, p. 197).

Organisational politics is a competitive strategy that uses bullying to control a workplace environment (Salin, 2003). Use of emotions as a strategic behaviour in an organisation to accomplish desired goals is a type of political behaviour (Liu et al., 2006). This argument is further supported by Ferris, Zinko, et al. (2007) and leaders' political skills influence their abusive/bullying behaviour at work. The leaders' political skills are defined as 'the ability of individuals to understand the work situation and others' behaviours, and to use this understanding to influence others to achieve personal goals and/or organisational goals' (Ahearn, Ferris, Hochwarter, Douglas, \& Ammeter, 2004). Further, Ferris, Zinko, et al. (2007) argued that politically skilled leaders know what to do in different situations and exhibit sincere, authentic, and genuine actions. They try to minimise negative consequences and achieve positive outcomes. They possess the skills and abilities to understand others, and act accordingly to achieve personal and/or organisational goals (Ferris et al., 2005). They further supported their argument that a politically skilled supervisor's strategic abuse is beneficial, especially for those employees who lack maturity and are in a tight deadline situation. On the other hand, a politically unskilled leader will not read the situation and their subordinates appropriately, and the possibility is that they would be engaged in classical bullying/abusive behaviour, with consequent negative effects upon employees.

In support of supervisory strategic abuse/bulling, Ferris, Treadway, et al. (2007) argued that this type of bullying not only controls the target but also the audience who observe the bullying, and hence in certain situations increases the employees' performance and productivity. This type of behaviour is usually used in a situation that is appropriate for the subordinates as well, which boosts subordinates' confidence and morale and as a result enhances their performance. Hence, the researcher, based on the existing literature review developed the appended below proposition.

Proposition 4 (b). Supervisory strategic abuse is positively correlated with employee's morale such that higher the supervisory strategic abuse, higher the employee's morale.

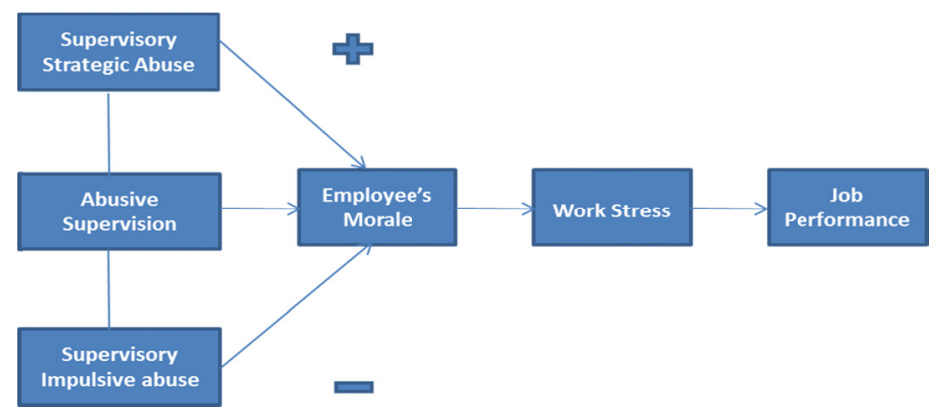

Figure 3. Conceptual Framework of abusive supervision 


\section{Conclusion}

The focus of present study is on abusive supervision. Narrowed down to abusive supervision at work, and discussed the literature around supervision and abusive supervision at work. The definition of supervision and abusive supervision, its effects and reasons for its occurrence have discussed. Abusive supervision was contrasted with related terms such as mobbing, bullying, workplace aggression, leader-member-exchange theory, deviant work behaviour, perceived social support, and perceived organisational and supervisory support. It is argued that these related terms such as mobbing, bullying, occupational violence and workplace aggression are closely related to abusive supervision and these terms are used inter-changeably with the term, abusive supervision especially in vertical relationships such as in the relationship of supervisor and subordinates. Leader-member-exchange theory identifies the reasons for its occurrence, and deviant work behaviour is the result of abusive supervision in an organisation. Social support, supervisory support, and organisational support can help to reduce the adverse effects of abusive supervision in an organisation. Further, the researcher with the help of literature review tried to bifurcate, the term abusive supervision, into two types of supervisory abuse e.g. supervisory impulsive and strategic abuse which will help the employees and organizations to differentiate between positive and negative aspects of supervisory abuse.

\section{Directions for Future Research}

The proposed model suggests multiple future research avenues. The proposed model suggests bifurcation of the construct of abusive supervision into its two sub-categories e.g. supervisory strategic abuse and supervisory impulsive abuse. So far majority of the studies rather almost all studies have focused on its negative aspect of supervisory abuse while there is a need to identify and highlight the positive aspect of abusive supervision which is largely based on organizational politics theory. Thus an important future research direction is to authenticate and confirm the distinction between these two manifestations e.g. supervisory impulsive and strategic abuse by studying their identical characteristics that will help to reduce the adverse effects of abusive supervision.

The second future research direction is to bifurcate the supervisory strategic abuse in terms of; (a). The supervisor use abuse as a tool in the best interest of organization to get the job done. (b). The supervisor use abuse as a tool in the best interest of his own self, may be his, the supervisor interest is to get promotion and get good reputation in an organization that's why he use abuse as a strategy to get the job done by his subordinate. And the third and an important future research direction is (c). When, the supervisor uses this tool of abuse to get the job done by his subordinates in their own (the subordinate's) best interest. This third characteristic of supervisor strategic abuse is referred by Tepper et al. (2012) as a 'Tough Love' which has close boundary similarities with the Ethical/Authentic leadership constructs.

Third future research direction is to apply this theoretical model in different cultural context e.g. eastern and western cultural context. By doing this will reveal rich data which will help to identify the characteristics of supervisor's strategic abuse in different cultural contexts.

\section{References}

Adams, A. (1992). Bullying at work. London: Virago.

Agarwal, R. S. (1983). Organization And Management. Delhi, India: Tata McGraw-Hill.

Ahearn, K. K., Ferris, G. R., Hochwarter, W. A., Douglas, C., \& Ammeter, A. P. (2004). Leader political skill and team performance. Journal of Management, 30(3), 309-327. http://dx.doi.org/10.1016/j.jm.2003. 01.004

Arnault, D. S. (2002). Help-Seeking and Social Support in Japanese Sojourners. Western Journal of Nursing Research, 24(3), 295-306. http://dx.doi.org/10.1177/01939450222045914

Arshadi, N., \& Damiri, H. (2013). The Relationship of Job Stress with Turnover Intention and Job Performance: Moderating Role of OBSE. Social and Behavioral Sciences, 84(9), 706-710.

Aryee, S., Li-Yun, S., Zhen Xiong, C., \& Debrah, Y. A. (2007). Antecedents and Outcomes of Abusive Supervision: Test of a Trickle-Down Model. Journal of Applied Psychology, 92(1), 191-201. http://dx.doi.org/10.1037/0021-9010.92.1.191

Baehr, M. E., \& Renck, R. (1958). The Definition and Measurement of Employee Morale. Administrative Science Quarterly, 3(2), 157-184. http://dx.doi.org/10.2307/2391015

Baird, J., \& Bradley, P. (1978). Communication Correlates of Employee Morale. Journal of Business Communication, 15(3), 47-56. http://dx.doi.org/10.1177/002194367801500306

Bandura, A. (1973). Aggression: A social Learning Analysis. Englewood Cliffs, NJ: Prentice-Hall. 
Bandura, A. (1986). Social foundations of thought and action. Englewood Cliffs, NJ: Prentice Hall.

Barney, J. (1991). Firm Resources and Sustained Competitive Advantage. Journal of Management, 17(1), 99.

Baron, R. A., \& Neuman, J. H. (1998). Workplace aggression - The iceberg beneath the tip of workplace violence: Evidence on its froms, frequency, and targets. Public Administration Quarterly, 21(4), 446-464.

Blau, G. (1981). An Empirical Investigation of Job Stress, Social Support, Service Length, and Job Strain. Organizational Behavior \& Human Performance, 27(2), 279.

Blau, P. M. (1964). Exchange and power in social life. NJ, USA: Transaction Publishers.

Bolino, M. C., \& Turnley, W. H. (1999). Measuring impression management in organizations: A scale development based on the Jones and Pittman taxonomy. Organizational Research Methods, 2(2), 187-206.

Bowen, D. E., \& Ostroff, C. (2004). Understanding HRM-Firm Performance Linkages: The role of the "Strength" of the HRM System. Academy of Management Review, 29(2), 203-221.

Bradburn, N. M. (1969). The structure of psychological well-being. England, Aldine: Oxford.

Breaux, D. M., Perrewé, P. L., Hall, A. T., Frink, D. D., \& Hochwarter, W. A. (2008). Time to try a little tenderness? The detrimental effects of accountability when coupled with abusive supervision. Journal of Leadership \& Organizational Studies, 15(2), 111-122. http://dx.doi.org/10.1177/1548051808321787

Brennan, W. J. (1996). Coping with aggression and violence at work. The Safety and Health Practitioner, 14(8), 46-49.

Brief, A. P. (1998). Attitudes in and around organizations: Foundations for organizational science. Thousand Oaks, CA, USA: Sage Publications, Inc.

Burton, J. P., \& Hoobler, J. M. (2006). Subordinate self-esteem and abusive supervision. Journal of Managerial Issues, 340-355.

Burton, J. P., \& Hoobler, J. M. (2011). Aggressive reactions to abusive supervision: The role of interactional justice and narcissism. Scandinavian Journal of Psychology, 52(4), 389-398. http://dx.doi.org/10.1111/j. 1467-9450.2011.00886.x

Cashdan, E., \& Downes, S. (2012). Evolutionary Perspectives on Human Aggression. Human Nature, 23(1), 1-4. http://dx.doi.org/10.1007/s12110-012-9133-0

Chang, C.-H., \& Lyons, B. J. (2012). Not all aggressions are created equal: A multifoci approach to workplace aggression. Journal of Occupational Health Psychology, 17(1), 79-92.

Chappell, D. (1995). How violent is Australian society? Canberra, Australia: Australian Institute of Criminology.

Chappell, D., \& Di Martino, V. (2006). Voilence at Work (3rd ed.). Geneva, Switzerland: International Labour Office.

Cohen, S. (1980). After effects of stress on human performance and social behavior: A review of research and theory. Psychological bulletin, 88(1), 82-108. http://dx.doi.org/10.1037/0033-2909.88.1.82

Cole, K. (1998). Supervision: Management in Action. New York \& Sydney: Prentice Hall.

Coon, D., \& Mitterer, O. J. (2008). An Introduction to Psychology: Gate Way to Mind and Behaviour (20th ed.). Belmont, CA.: Wadsworth Cengage Learning.

Crick, N. R., \& Dodge, K. A. (1994). A review and reformulation of social information-processing mechanisms in children's social adjustment. Psychological Bulletin, 115(1), 74-101. http://dx.doi.org/10.1037/00332909.115.1.74

Dansereau, F. J., Cashman, J., \& Graen, G. (1973). Instrumentality theory and equity theory as complementary approaches in predicting the relationship of leadership and turnover among managers. Organizational Behavior and Human Performance, 10(2), 184-200. http://dx.doi.org/10.1016/0030-5073(73)90012-3

Dansereau, F. J., Graen, G., \& Haga, W. J. (1975). A vertical dyad linkage approach to leadership within formal organizations: A longitudinal investigation of the role making process. Organizational Behavior and Human Performance, 13(1), 46-78. http://dx.doi.org/10.1016/0030-5073(75)90005-7

Dienesch, R. M., \& Liden, R. C. (1986). Leader-Member Exchange Model of Leadership: A Critique and Further Development. The Academy of Management Review, 11(3), 618-634.

Duffy, E. (1995). Horizontal violence: A conundrum for nursing. Collegian, 2(2), 5-17. http://dx.doi.org/ 


\subsection{6/S1322-7696(08)60093-1}

Duffy, E., Michelle, K., Ganster, D. C., \& Pagon, M. (2002). Social Undermining in the Workplace. Academy of Management Journal, 45(2), 331-351. http://dx.doi.org/10.2307/3069350

Dunlop, P. D., \& Lee, K. (2004). Workplace deviance, organizational citizenship behavior, and business unit performance: the bad apples do spoil the whole barrel. Journal of Organizational Behavior, 25(1), 67-80. http://dx.doi.org/10.1002/job.243

Duschek, S. (2004). Inter-Firm Resources and Sustained Competitive Advantage. Management Revue, 15(1), 53-73.

Dysvik, A., \& Kuvaas, B. (2012). Perceived supervisor support climate, perceived investment in employee development climate, and business - unit performance. Human Resource Management, 51(5), 651-664. http://dx.doi.org/10.1002/hrm.21494

Einarsen, S. (1999). The nature and causes of bullying at work. International Journal of Manpower, 20(1/2), 16-27. http://dx.doi.org/10.1108/01437729910268588

Eisenberger, R., \& Stinglhamber, F. (2011). Perceived organizational support Perceived organizational support: Fostering enthusiastic and productive employees. (pp. 25-60). Washington, D.C. US: American Psychological Association.

Everton, W. J. e. e. e., Jolton, J. A., \& Mastrangelo, P. M. (2007). Be nice and fair or else: Understanding reasons for employees' deviant behavior. Journal of Management Development, 26(2), 117-131. http://dx.doi.org/10.1108/02621710710726035

Falcione, R. L. (1974). Communication climate and satisfaction with immediate supervision. Journal of Applied Communication Research, 2(1), 13-20. http://dx.doi.org/10.1080/00909887409360190

Ferris, G. R., Treadway, D. C., Kolodinsky, R. W., Hochwarter, W. A., Kacmar, C. J., Douglas, C., \& Frink, D. D. (2005). Development and validation of the political skill inventory. Journal of Management, 31(1), 126-152. http://dx.doi.org/10.1177/0149206304271386

Ferris, G. R., Treadway, D. C., Perrewé, P. L., Brouer, R. L., Douglas, C., \& Lux, S. (2007). Political skill in organizations. Journal of Management, 33(3), 290-320. http://dx.doi.org/10.1177/0149206307300813

Ferris, G. R., Zinko, R., Brouer, R. L., Buckley, M. R., \& Harvey, M. G. (2007). Strategic bullying as a supplementary, balanced perspective on destructive leadership. The Leadership Quarterly, 18(3), 195-206. http://dx.doi.org/10.1016/j.leaqua.2007.03.004

Festinger, L. (1957). A theory of cognitive dissonance. Standford, CA: Standford Unviersity Press.

Folger, R., \& Baron, R. A. (1996). Violence and hostility at work: A model of reactions to perceived injustice. In E. Q. Bulatao (Ed.), Violence on the job: Identifying risks and developing solutions (p. 439). Retrieved from http://psycnet.apa.org/books/10215/002

Ford, S. (2004). Workplace stress: Environmental and individual factors. InPsych, 18(5), 7-12.

French, G., \& Morgan, P. (2002). Addressing workplace violence. Legal Focus on Risk and Insurance Strategies, 6(2), 14-19.

Friend, K. E. (1982). Stress and performance: Effects of subjective work load and time urgency. Personnel Psychology, 35(3), 623-633. http://dx.doi.org/10.1111/j.1744-6570.1982.tb02214.x

Ganster, D. C., \& Perrewé, P. L. (2011). Theories of occupational stress. In J. C. Quick \& L. E. Tetrick (Eds.), Handbook of occupational health psychology (2nd ed.). (pp. 37-53). Washington, DC US: American Psychological Association.

Ganster, D. C., \& Rosen, C. C. (2013). Work Stress and Employee Health: A Multidisciplinary Review. Journal of Management, 39(5), 1085-1122. http://dx.doi.org/10.1177/0149206313475815

Government of South Australia. (2013). Safe Wok SA. Retrieved August 9, 2013, from http://www.safework.sa.gov.au/

Graen, G., Novak, M. A., \& Sommerkamp, P. (1982). The effects of leader-member exchange and job design on productivity and satisfaction: Testing a dual attachment model. Organizational Behavior and Human Performance, 30(1), 109-131. http://dx.doi.org/10.1016/0030-5073(82)90236-7

Grice, T., Sheehan, M., McCarthy, P., Barker, M., \& Henderson, M. (2003). Workplace bullying: Issues, impacts 
and interventions. Australian Journal of Psychology, 55, 125-125.

Griffin, M. A., \& Clarke, S. (2011). Stress and well-being at work. In S. Zedeck (Ed.), APA handbook of industrial and organizational psychology, Vol 3: Maintaining, expanding, and contracting the organization. (pp. 359-397). Washington, DC US: American Psychological Association.

Groeblinghoff, D., \& Becker, M. (1996). A case study of mobbing and the clinical treatment of mobbing victims. European Journal of Work and Organizational Psychology, 5(2), 277-294. http://dx.doi.org/10.1080/13594 329608414859

Gupta, N., \& Beehr, T. A. (1979). Job stress and employee behaviors. Organizational behavior and human performance, 23(3), 373-387. http://dx.doi.org/10.1016/0030-5073(79)90004-7

Harmon-Jones, E. (1999). Toward an understanding of the motivation underlying dissonance effects: Is the production of aversive consequences necessary? In E. Harmon-Jones \& J. Mills (Eds.), Cognitive dissonance: Progress on a pivotal theory in social psychology. (pp. 71-99). American Psychological Association.

Harrell, T. W. (1958). Industrial psychology (Rev. ed.). Oxford England: Rinehart.

Harris, K. J., Kacmar, K. M., \& Zivnuska, S. (2007). An investigation of abusive supervision as a predictor of performance and the meaning of work as a moderator of the relationship. The Leadership Quarterly, 18(3), 252-263. http://dx.doi.org/10.1016/j.leaqua.2007.03.007

Hart, P. M., \& Cotton, P. (2003). Conventional wisdom is often misleading: Police stress within an organisational health framework. Occupational stress in the service professions, 103-141. http://dx.doi.org/10.1201/9780203422809.ch4

Hart, P. M., \& Wearing, A. J. (1995). Occupational stress and well-being: A systematic approach to research, policy, and practice. In P. Cotton (Ed.), Psychological health in the workplace: Understanding \& managing occupational stress. (pp. 185-216). Carlton South VIC Australia: Australian Psychological Society.

Hart, P. M., Wearing, A. J., \& Headey, B. (1995). Police stress and well - being: Integrating personality, coping and daily work experiences. Journal of Occupational and Organizational Psychology, 68(2), 133-156.

Harvey, P., Stoner, J., Hochwarter, W., \& Kacmar, C. (2007). Coping with abusive supervision: The neutralizing effects of ingratiation and positive affect on negative employee outcomes. The Leadership Quarterly, 18(3), 264-280. http://dx.doi.org/10.1016/j.leaqua.2007.03.008

Hauge, L. J., Skogstad, A., \& Einarsen, S. (2010). Role stressors and exposure to workplace bullying: Causes or consequences of what and why? European Journal of Work and Organizational Psychology, 20(5), 610-630. http://dx.doi.org/10.1080/1359432X.2010.482264

Health \& Safety Authority. (2013). Bullying at Work. Retrieved May 8, 2013, from http://www.hsa.ie/eng/ Topics/Bullying_at_Work/

Hill, I. B. (1954). Factors Influencing Employee Morale. American Journal of Mental Deficiency, 58(3), 371-374.

Hobman, E. V., Restubog, S. L. D., Bordia, P., \& Tang, R. L. (2009). Abusive Supervision in Advising Relationships: Investigating the Role of Social Support. Applied Psychology: An International Review, 58(2), 233-256. http://dx.doi.org/10.1111/j.1464-0597.2008.00330.x

Hockley, C. (2002). Silent Hell, workplace violence \& bullying (1st ed.). Peacock Publications.

Hoff, L. (1990). Battered Women as Survivors. London: Routledge.

Hogh, A., \& Dofradottir, A. (2001). Coping with bullying in the workplace. European Journal of Work and Organizational Psychology, 10(4), 485-495. http://dx.doi.org/10.1080/13594320143000825

Hoobler, J. M., \& Brass, D. J. (2006). Abusive Supervision and Family Undermining as Displaced Aggression. Journal of Applied Psychology, 91(5), 1125-1133. http://dx.doi.org/10.1037/0021-9010.91.5.1125

Hornstein, H. A. (1996). Brutal bosses and their prey. Riverhead books New York.

Hutchison, S., Sowa, D., Eisenberger, R., \& Huntington, R. (1986). Perceived organizational support. Journal of Applied Psychology, 71(3), 500-507. http://dx.doi.org/10.1037/0021-9010.71.3.500

Invernizzi, G. (2000). New concepts on the psychology of the workplace relationships: The so called 'mobbing'. New Trends in Experimental \& Clinical Psychiatry, 16(1-4). 
Ivancevich, J. M., \& Donnelly Jr, J. H. (1974). A Study of Role Clarity and Need for Clarity for Three Occupational Groups. Academy of Management Journal, 17(1), 28-36. http://dx.doi.org/10.2307/254768

Jackson, S. E., \& Schuler, R. S. (1985). A meta-analysis and conceptual critique of research on role ambiguity and role conflict in work settings. Organizational Behavior and Human Decision Processes, 36(1), 16-78.

Jamal, M. (1984). Job stress and job performance controversy: An empirical assessment. Organizational Behavior and Human Performance, 33(1), 1-21. http://dx.doi.org/10.1016/0030-5073(84)90009-6

Jamal, M. (2011). Job Stress, Job Performance and Organizational Commitment in a Multinational Company: An Empirical Study in two Countries. International Journal of Business \& Social Science, 2(20), 20-29.

Jian, Z., Kwan, H. K., Qiu, Q., Liu, Z. Q., \& Yim, F. H.-k. (2011). Abusive supervision and frontline employees' service performance. The Service Industries Journal, 32(5), 683-698. http://dx.doi.org/10.1080/02642069. 2011.614338

Jones, E. E., \& Pittman, T. S. (1982). Toward a general theory of strategic self-presentation. In J. Suls (Ed.), Psychological perspectives on the self(Vol. 1, pp. 231-262). Hillsdale, NJ Erlbaum.

Kang, J. H., \& Jensen, J. M. (2009). Cultural Matters in Entrepreneurial Firms: Abusive Supervision and Its Consequences. Washington.

Kathirvel, N. (2010). A Study on the Morale of Employees with Reference to Textile Industries in Coimbatore. IUP Journal of Management Research, 9(3), 61-81.

Khan, S. N., Qureshi, I. M., \& Ahmad, H. I. (2010). Abusive Supervision and Negative Employee Outcomes. European journal of social sciences, 15(4), 490-500.

Labour Laws. (2002). Retrieved May 8, 2013, from http://www.hrsdc.gc.ca/eng/labour/labour_law/dllc/20022003.shtml

LaRocco, J. M., House, J. S., \& French Jr, J. R. P. (1980). Social Support, Occupational Stress, and Health. Journal of Health \& Social Behavior, 21(3), 202-218.

LaRocco, J. M., \& Jones, A. P. (1978). Co-worker and leader support as moderators of stress-strain relationships in work situations. Journal of Applied Psychology, 63(5), 629-634.

Lazarus, R. S. (1993). From psychological stress to the emotions: A history of changing outlooks. Annual Review of Psychology, 44(1), 1.

LePine, J. A., Podsakoff, N. P., \& LePine, M. A. (2005). A meta-analytic test of the challenge stressor-hindrance stressor framework: An explanation for inconsistent relationships among stressors and performance. Academy of Management Journal, 48(5), 764-775.

Leymann, H. (1990). Mobbing and Psychological Terror at Workplaces. Violence and Victims, 5(2), 119-126.

Leymann, H. (1998). Some Historical Notes: Research and the Term Mobbing. The Mobbing Encyclopaedia.

Leymann, H., \& Gustavsson, B. (1984). Psychological violence at workplaces: Two exploratory studies.

Lian, H., Ferris, D. L., \& Brown, D. J. (2012). Does Power Distance Exacerbate or Mitigate the Effects of Abusive Supervision? It Depends on the Outcome. Journal of Applied Psychology, 97(1), 107-123.

Liden, R. C., \& Graen, G. (1980). Generalizability of the Vertical Dyad Linkage Model of Leadership. Academy of Management Journal, 23(3), 451-465. http://dx.doi.org/10.2307/255511

Lines, D. (2008). The Bullies: Understanding Bullies and Bullying (1st ed.). London and Philadelphia: Jessica Kingsley.

Liu, Y., Ferris, G. R., Treadway, D. C., Prati, M. L., Perrewé, P. L., \& Hochwarter, W. A. (2006). 10 The emotion of politics and the politics of emotions: Affective and cognitive reactions to politics as a stressor. Handbook of organizational politics, 161. http://dx.doi.org/10.4337/9781847201874.00018

MacIntosh, J. (2006). Tackling workplace bullying. Issues in Mental Health Nursing, 27, 665-679.

Maher, J. R., \& Piersol, D. T. (1970). Perceived clarity of individual job objectives and of group mission as correlates of organizational morale. Journal of Communication, 20, 125-133.

Mariano, M. P., \& María, I. S. S. (2008). Workplace mobbing and effects on workers' health. The Spanish Journal of Psychology, 11(1), 219-227. http://dx.doi.org/10.1017/S1138741600004261

Martinko, M. J., Sikora, D., \& Harvey, P. (2012). The Relationships Between Attribution Styles, LMX, and 
Perceptions of Abusive Supervision. Journal of Leadership \& Organizational Studies, 19(4), 397-406.

Meglino, B. M. (1977). Stress and performance: Are they always incompatible. Supervisory Management, 22(3), 2-12.

Mehdi, A., Raju, R. M., \& Mukherji, A. (2012). Abusive Supervision and Employee Attrition: A Study of Executives in the Indian High Technology Sector. Competition Forum, 10(2), 42-48.

Mitchell, M. S., \& Ambrose, M. L. (2007). Abusive Supervision and Workplace Deviance and the Moderating Effects of Negative Reciprocity Beliefs. Journal of Applied Psychology, 92(4), 1159-1168.

Motowidlo, S. J. (2003). Job Performance. Handbook of Psychology. John Wiley \& Sons, Inc.

Muse, L., Harris, S., \& Feild, H. (2003). Has the Inverted-U Theory of Stress and Job Performance Had a Fair Test? Human Performance, 16(4), 349-364. http://dx.doi.org/10.1207/S15327043HUP1604_2

Namie, G. (2010). Workforce Bullying Institute. Retrieved May 6, 2013, from http://www.workplacebullying. org/wbiresearch/2010-wbi-national-survey/

Niedl, K. (1996). Mobbing and well-being: Economic and personnel development implications. European Journal of Work and Organizational Psychology, 5(2), 239-249.

Olweus, D. (1978). Aggression in the schools: Bullies and whipping boys. Oxford England: Hemisphere.

Pestonjee, D. M., \& Singh, A. P. (1977). Supervisory orientation and employees' morale. Journal of Occupational Psychology, 50(2), 85-91. http://dx.doi.org/10.1111/j.2044-8325.1977.tb00362.x

Rafferty, A. E., \& Restubog, S. L. D. (2011). The Influence of Abusive Supervisors on Followers' Organizational Citizenship Behaviours: The Hidden Costs of Abusive Supervision. British Journal of Management, 22(2), 270-285. http://dx.doi.org/10.1111/j.1467-8551.2010.00732.x

Rahimić, Z., \& Kovačević, J. (2009). The Leader-Member Exchange in Teams of B \& H Companies. Odnosi Lidera I Sljedbenika U Timovima Bosanskohercegovackih Kompanija, (29), 89-104.

Renwick, D., \& MacNeil, C. M. (2002). Line manager involvement in careers. Career Development International, 7(7), 407-414. http://dx.doi.org/10.1108/13620430210449939

Richman, J. A., Flaherty, J. A., Rospenda, K. M., \& Christensen, M. L. (1992). Mental health consequences and correlates of reported medical student abuse. JAMA: The journal of the American Medical Association, 267(5), 692-694. http://dx.doi.org/10.1001/jama.1992.03480050096032

Rizzo, J. R., House, R. J., \& Lirtzman, S. I. (1970). Role conflict and ambiguity in complex organizations. Administrative science quarterly, 150-163. http://dx.doi.org/10.2307/2391486

Roberts, S. J. (1983). Oppressed group behavior: Implications for nursing. Advances in Nursing Science, 5(4), 21-30. http://dx.doi.org/10.1097/00012272-198307000-00006

Robinson, S. L., \& Bennett, R. J. (1995). A typology of deviant workplace behaviors: A multidimensional scaling study. Academy of Management Journal, 38(2), 555-572.

Sadler, M. E., Hunger, J. M., \& Miller, C. J. (2010). Personality and impression management: Mapping the Multidimensional Personality Questionnaire onto 12 self-presentation tactics. Personality and Individual Differences, 48(5), 623-628. http://dx.doi.org/10.1016/j.paid.2009.12.020

Salin, D. (2003). Bullying and organisational politics in competitive and rapidly changing work environments. International Journal of Management and Decision Making, 4(1), 35-46.

Sanders, A. F. (1983). Towards a model of stress and human performance. Acta Psychologica, 53(1), 61-97.

Selye, H. (1976). The Stress of Life. New York: McGraw-Hill, Book Co.

Shaw, M. E. (1954). Some effects of unequal distribution of information upon group performance in various communication nets. The Journal of Abnormal and Social Psychology, 49(4), 547-553.

Shoss, M. K., Eisenberger, R., Restubog, S. L. D., \& Zagenczyk, T. J. (2013). Blaming the organization for abusive supervision: The roles of perceived organizational support and supervisor's organizational embodiment. Journal of Applied Psychology, 98(1), 158-168.

Siporin, M. (1965). Deviant Behavior Theory in Social Work: Diagnosis \& Treatment. Social Work, 10(3), 59-67.

Taylor, M. (2005). The relationships between workplace violence, deviant workplace behavior, ethical climate, organizational justice, and abusive supervision. (66), ProQuest Information \& Learning, US. Retrieved from 
http://ezproxy.deakin.edu.au/login?url=http://search.ebscohost.com/login.aspx?direct=true\&db=psyh \&AN=2005-99014-229\&site $=$ ehost-live\&scope $=$ site

Tehrani, N. (2012). Workplace Bullying: Symptoms and Solutions. New York: Routledge.

Tepper, B. J. (2000). Consequences of abusive supervision. Academy of Management Journal, 43(2), 178-190.

Tepper, B. J. (2007). Abusive supervision in work organizations: Review, synthesis, and research agenda. Journal of Management, 33(3), 261-289. http://dx.doi.org/10.1177/0149206307300812

Tepper, B. J., Duffy, E., K., M., \& Breaux-Siognet, D. M. (2012). Abusive supervision as political activity: Distinguishing impulsive and strategic expressions of downward hostility. In G. R. Ferris, \& D. C. Treadway (Eds.), Politics in organizations: Theory and research considerations (pp. 191-212). New York, NY US: Routledge/Taylor \& Francis Group.

Tepper, B. J., Duffy, M. K., Henle, C. A., \& Lambert, L. S. (2006). Procedural injustice, victim precipitation, and abusive supervision. Personnel Psychology, 59(1), 101-123.

Tepper, B. J., Duffy, M. K., Hoobler, J., \& Ensley, M. D. (2004). Moderators of the relationships between coworkers' organizational citizenship behavior and fellow employees' attitudes. The Journal Of Applied Psychology, 89(3), 455-465. http://dx.doi.org/10.1037/0021-9010.89.3.455

Tepper, B. J., Henle, C. A., Lambert, L. S., Giacalone, R. A., \& Duffy, M. K. (2008). Abusive Supervision and Subordinates' Organization Deviance. Journal of Applied Psychology, 93(4), 721-732.

Tepper, B. J., Moss, S. E., \& Duffy, M. K. (2011). Predictors of abusive supervision: Supervisor perceptions of deep-level dissmiliarity, relationship conflict, and subordinate performance. Academy of Management Journal, 54(2), 279-294. http://dx.doi.org/10.5465/AMJ.2011.60263085

Tepper, B. J., Moss, S. E., Lockhart, D. E., \& Carr, J. C. (2007). Abusive supervision, upward maintenance communication, and subordinates' psychological distress. Academy of Management Journal, 50(5), 1169-1180. http://dx.doi.org/10.2307/20159918

Thau, S., Bennett, R. J., Mitchell, M. S., \& Marrs, M. B. (2009). How management style moderates the relationship between abusive supervision and workplace deviance: An uncertainty management theory perspective. Organizational Behavior and Human Decision Processes, 108(1), 79-92.

Tosi, H. (1971). Organization Stress as a Moderator of the Relationship Between Influence and Role Response. Academy of Management Journal, 14(1), 7-20. http://dx.doi.org/10.2307/254707

Truss, C. (2001). Complexities and Controversies in Linking HRM with Organizational Outcomes. Journal of Management Studies, 38(8), 1121-1149. http://dx.doi.org/10.1111/1467-6486.00275

Turnbull, J. (1995). Violence. Hitting back at the bullies. Nursing times, 91(3), 24-27.

Vecchio, R. P. v. n. e., \& Brazil, D. M. (2007). Leadership and Sex-Similarity: A Comparison in a Military Setting. Personnel Psychology, 60(2), 303-335. http://dx.doi.org/10.1111/j.1744-6570.2007.00075.x

Westman, M., \& Eden, D. (1991). Implicit stress theory: The spurious effects of stress on performance ratings. Journal of Social Behavior \& Personality, 6(7), 127-140.

Wu, T.-Y., \& Changya Hu. (2009). Abusive Supervision and Employee Emotional Exhaustion: Dispositional Antecedents and Boundaries. Group \& Organization Management, 34(2), 143-169.

Yıldız, S. (2007). A 'New' Problem in the Workplace: Psychological Abuse (Bullying). Journal of Academic Studies, 9(34), 113-128.

Zapf, D., Knorz, C., \& Kulla, M. (1996). On the relationship between mobbing factors, and job content, social work environment, and health outcomes. European Journal of Work and Organizational Psychology, 5(2), 215-237. http://dx.doi.org/10.1080/13594329608414856

Zellars, K. L., Tepper, B. J., \& Duffy, M. K. (2002). Abusive supervision and subordinates' organizational citizenship behavior. $J$ Appl Psychol, 87(6), 1068-1076. http://dx.doi.org/10.1037/0021-9010.87.6.1068

\section{Copyrights}

Copyright for this article is retained by the author(s), with first publication rights granted to the journal.

This is an open-access article distributed under the terms and conditions of the Creative Commons Attribution license (http://creativecommons.org/licenses/by/3.0/). 